\title{
PENGEMBANGAN LKS BERDASARKAN MASALAH KONTEKSTUAL PADA MATERI OPERASI HITUNG BENTUK ALJABAR
}

\author{
Kornelis Jaha Loli, Nia Wahyu Damayanti, Eko Yuniarto \\ Universitas Wisnuwardhana Malang \\ e-mail: wahyu nia07@yahoo.co.id
}

\begin{abstract}
Abstrak
Berdasarkan hasil penelitian terhadap kesulitan yang dihadapi oleh guru matematika dan siswa di tingkat SMP, pemahaman yang rendah dari siswa tentang operasi hitung bentuk aljabar dikarenakan siswa tidak mampu menghubungkan antara apa yang mereka pelajari dengan pengetahuan tersebut dimanfaatkan dalam kehidupan nyata. Penggunaan perangkat pembelajaran yang berdasarkan masalah kontekstual akan sangat membantu siswa. Metode pengembangan yang digunakan adalah Research and Developmepment dengan menggunakan model pengembangan ADDIE. Pengembangan ini dimaksudkan untuk mengetahui kevalidan (yang dihasilkan dari hasil validasi) dan keefektifan (yang dihasilkan dari hasil angket dan nilai siswa). Dari hasil penelitian dapat dikatakan valid karena diperoleh hasil validasi oleh ahli materi dan ahli desain pembelajaran yaitu $87,05 \%$, dan efektif karena angket siswa sebesar $85,93 \%$, dan nilai tes evaluasi dari 8 siswa telah mencapai nilai KKM yang ditentukan oleh sekolah yaitu 70 .
\end{abstract}

Kata Kunci : Pengembangan, LKS Berdasarkan Masalah Kontekstual, Operasi Hitung
Bentuk Aljabar

Abstract

Based on the results of the study of the difficulties faced by mathematics teachers and students at the junior level, students' low understanding on the operation of the algebraic count is driven by the students inability in integrating between what they learn with the knowledge and how it utilized in real life. The use of learning tools based on contextual issues will significantly assist the students. The development method used is Research and Development using the ADDIE development model. This development is intended to determine validity (resulting from validation results) and effectiveness (resulting from questionnaires and student scores). The result of research had been validated through validation result by material expert and design expert of learning in percentage of $87,05 \%$. The percentage of usefulness gain through the student questionnaire is equal to $85,93 \%$, and value of evaluation test from 8 students have reached the standard value determined by the school that is 70 .

Keywords: Development, Contextual Problems Based Worksheet (LKS), Algebraic Forms

\section{PENDAHULUAN}

Berdasarkan kajian terhadap kesulitan yang dihadapi oleh guru matematika dan siswa di tingkat SMP, pemahaman yang rendah dari siswa tentang operasi hitung bentuk aljabar menunjukkan bahwa masih banyak siswa yang sulit membedakan antara suku sejenis dengan tidak sejenis, makna koefisien, sehingga tidak mampu menyelesaikan 
operasi hitung bentuk aljabar dengan baik. Pemahaman merupakan hal yang mendasar dalam pembelajaran matematika (Damayanti \& Mayangsari, 2017b). Hal ini dikarenakan siswa tidak mampu menghubungkan antara apa yang mereka pelajari dengan bagaimana pengetahuan tersebut dimanfaatkan dalam kehidupan nyata. Untuk itu, guru perlu mengaitkan materi yang diajarkan dengan kondisi sekitar atau kehidupan sehari-hari. Untuk mengatasi masalah tersebut, penggunaan perangkat pembelajaran akan sangat membantu, terutama perangkat pembelajaran yang berdasarkan masalah kontekstual. Siswa membutuhkan pemahaman matematika untuk menyelesaikan masalah (Damayanti \& Mayangsari, 2017a). Dengan belajar berdasarkan masalah kontekstual, diharapkan apa yang dimiliki siswa sebagai hasil belajar lebih tertanam dengan baik, karena masalah yang dihadapkan tidak jauh dari kehidupan sehari-hari.

Sebagian besar dari siswa tidak mampu menghubungkan antara apa yang mereka pelajari dengan bagaimana pengetahuan tersebut akan digunakan atau dimanfaatkan dalam kehidupan nyata (Masnur, 2008). Guru yang memilih untuk menggunakan LKS dalam pembelajaran apalagi yang menyusun sendiri perlu memperhatikan banyak hal. Pemilihan LKS ini harus sesuai dengan fungsi dan tujuan penyusunan dan pembuatan Lembar Kerja Siswa (LKS). Fungsi penyusunan dan penggunaan Lembar Kegiatan Siswa (LKS) dalam pembelajaran secara umum adalah: (a) sebagai bahan ajar yang bisa meminimalkan peran pendidik; (b) sebagai bahan ajar yang mempermudah peserta didik untuk memahami materi yang diberikan; (c) dan bahan ajar yang diringkas dan kaya tugas untuk berlatih; (d) memudahkan pelaksanaan pengajaran kepada peserta didik (Prastowo, 2012).

LKS adalah panduan siswa yang digunakan untuk melakukan kegiatan penyelidikan dan pemecahan masalah (Trianto, 2010). Dapat disimpulkan bahwa LKS merupakan bahan ajar cetak yang berupa lembar-lembar yang berisi materi, ringkasan dan petunjuk-petunjuk pelaksanaan tugas pembelajaran yang harus dikerjakan siswa yang mengacu pada kompetensi dasar yang harus dicapai. LKS ini akan dibuat berdasarkan masalah kontekstual. Masalah kontekstual adalah masalah dimana situasi masalah tersebut merupakan pengalaman nyata bagi siswa yang berkaitan dengan kehidupan sehari-hari. Dengan masalah-masalah kontekstual, materi dan proses pembelajaran diharapkan lebih bermakna dan lebih tertanam dalam diri siswa serta diharapkan siswa akan mudah memahami setiap maasalah yang disajikan karena berkaitan dengan kehidupan sehari-hari.

\section{METODE}


Model pengembangan yang digunakan adalah model ADDIE yang dikembangkan oleh Dick and Carey melalui beberapa tahap yaitu Analysis (Analisis), Design (Desain), Development (Pengembangan), Implementation (Implementasi), dan Evaluation (Evaluasi). Pada tahap analisis, terdapat dua tahap yakni analisis kinerja yang dilakukan adalah menganalisis tujuan umum pembelajaran matematika kelas VIII SMPK Wignya Mandala Tumpang, dan analisis kebutuhan yang dilakukan adalah menganalisis standar kompetensi dan kompetensi dasar yang harus dicapai oleh siswa. Tahap desain adalah tahap yang bertujuan untuk merancang bentuk perangkat pembelajaran yaitu LKS. Sedangkan pada tahap pengembangan akan dilakukan penilaian ahli yaitu validasi oleh ahli materi pembelajaran dan validasi oleh ahli desain pembelajaran serta dilakukan uji coba pengembangan yang nantinya akan dilakukan angket siswa dan tes evaluasi (uji kompetensi akhir).

Subjek uji coba pada pengembangnan ini adalah uji coba kelompok kecil yaitu 8 siswa kelas VIII SMPK Wignya Mandala Tumpang. Instrumen pengumpulan data meliputi lembar validasi, angket siswa dan tes. Teknik pengumpulan data yang digunakan untuk validasi dan mengevaluasi perangkat pembelajaran yang dikembangkan dalam penelitian pengembangan ini adalah kuesioner dan angket. Setelah data dikumpulkan maka data akan divalidasi yang kemudian akan dianalisis, data yang dianalisis adalah lembar validasi dan angket yang menggunakan analisis acuan yang ditetapkan oleh Arikunto (2010) menggunakan rumus :

$$
\text { Presentase }=\frac{\sum(\text { Jawaban } \times \text { bobot tiap pilihan })}{n \times \text { bobot tertinggi }} \times 100 \%
$$

Keterangan :

$\Sigma \quad:$ Jumlah

$n \quad$ : Jumlah seluruh butir angket data yang dianalisis adalah lembar validasi dan angket serta tes. Dari presentase yang telah diperoleh kemudian ditransformasikan kedalam kalimat yang bersifat kualitatif. Untuk menentukan kriteria dilakukan interpretasi data dengan cara seperti Tabel 1.

Tabel 1. Interpretasi data

\begin{tabular}{lll}
\hline No. & Interval & Kriteria \\
\hline 1 & $81 \%-100 \%$ & Sangat Baik \\
2 & $61 \%-80 \%$ & Baik \\
3 & $41 \%-60 \%$ & Cukup \\
4 & $21 \%-40 \%$ & Kurang \\
5 & $0 \%-20 \%$ & Kurang Sekali \\
\hline
\end{tabular}

Diadaptasi dari Arikunto (2009)

Sedangkan tes akan dianalisis untuk mengetahui apakah LKS tersebut efektif digunakan atau masih perlu revisi. LKS dikatakan efektif apabila memenuhi kriteria keefektifan, yaitu apabila hasil nilai tes telah mencapai nilai KKM yang ditetapkan oleh sekolah tempat uji coba 
produk yaitu 70 . Setelah itu akan dilakukan revisi sesuai dengan komentar dan saran dari para ahli.

\section{HASIL DAN PEMBAHASAN}

Sesuai dengan model pengembangan yang dipakai, maka penyajian data uji coba meliputi hasil tahap analisis yang meliputi dua tahap yaitu analisis kinerja Pada tahap analisis kerja ini yang dilakukan adalah mengidentifikasi tujuan umum pembelajaran Matematika kelas VIII SMPK Wignya Mandala Tumpang. Berdasarkan rumusan tujuan pembelajaran pada standar kompetensi dan kompetensi dasar, maka perangkat pembelajaran matematika ini bertujuan untuk mengembangkan pengetahuan, pemahaman dan kemampuan analisis terhadap materi operasi hitung bentuk aljabar yang meliputi (1) Siswa dapat menjelaskan pengertian koefisien, variabel, konstanta, suku sejenis, suku satu, suku dua, dan suku tiga dalam variabel yang sama atau beda; (2) Siswa dapat menyelesaikan operasi tambah, kurang, kali, pangkat, dan bagi.

Analisis kebutuhan dilakukan dengan cara menganalisis standar kompetensi dan dan kompetensi dasar beserta indikatornya (Listiyani dan Widayati, 2012). Berdasarkan pada kompetensi dasar beserta indikatornya, siswa diharapkan dapat menjelaskan pengertian koefisien, variabel, konstanta, suku sejenis, suku satu, suku dua, suku tiga dalam variabel yang sama atau yang beda. Menyelesaikan operasi tambah, kurang, kali, pangkat dari suku satu, suku dua, dan bagi.

Hasil dari perancangan ini adalah rancangan LKS. Untuk mendukung pelaksanaan LKS, maka dibuat rancangan RPP dan instrumen penelitian. Desain produk berupa LKS yang dirancang berdasarkan unsur-unsur yang terdapat pada LKS sebagai bahan ajar dengan melakukan modifikasi berdasarkan masalah kontekstual. LKS berdasarkan masalah kontekstual ini terdiri dari beberapa komponen, yaitu halaman sampul (cover), kata pengantar, daftar isi, pendahuluan (peta konsep, kompetensi dasar, indikator dan tujuan pembelajaran), penyampaian materi, soal latihan, dan uji kompetensi akhir (soal evaluasi) berdasarkan masalah kontekstual, serta yang terakhir adalah daftar pustaka. Instrumen penelitian yang dihasilkan adalah (a) Lembar validasi, angket siswa berisi petunjuk pengisian, keterangan skor, tabel penilaian yang berisi aspek yang dinilai dan skor; (b) Angket siswa tentang LKS berisi petunjuk penilaian dan pertanyaan tentang materi/isi LKS; (c) Tes hasil belajar berisi soal tes kompetensi akhir.

Setelah didapat rancangan perangkat pembelajaran, maka selanjutnya adalah tahap development (pengembangan). Pada tahap ini meliputi dua langkah yaitu penilaian ahli dan uji coba pengembangan (Astuti dan Setiawan, 2013). Hasil dari tahap pengembangan ini terdiri dari hasil validasi dan hasil uji coba pengembangan lapangan. Hasil validasi digunakan untuk menilai validitas LKS sebelum pelaksanaan uji coba lapangan. Dari hasil 
validasi ini akan diketahui apakah LKS ini masih perlu direvisi sebelum uji coba atau telah siap di uji cobakan di lapangan tanpa revisi. Sedangkan hasil uji coba lapangan digunakan untuk menilai keefektifan LKS. Kemudian hasil uji coba pengembangan dilapangan tersebut menjadi dasar kepastian apakah LKS tersebut perlu direvisi kembali atau tidak.

Validasi ahli dilakukan oleh dua ahli yaitu ahli materi dan ahli desain. Validator ahli materi meliputi seorang dosen matematika di Universitas Wisnuwardhana Malang dan seorang guru bidang studi matematika kelas VIII di SMPK Wignya Mandala Tumpang. Serta validator ahli materi yaitu seorang dosen di Universitas Wisnuwardhana Malang. Hasil validasi ahli seperti terlihat pada Tabel 2.

Tabel 2. Hasil Validasi LKS Oleh Ahli Materi dan Ahli Desain

\begin{tabular}{lll}
\hline \multicolumn{2}{l}{ Skor Rata-Rata Hasil Validasi oleh } & $\begin{array}{l}\text { Skor Rata-Rata Hasil Validasi oleh Ahli } \\
\text { Mhleri dan Ahli Desain }\end{array}$ \\
\cline { 1 - 2 } Ahli Materi & Ahli Desain & $87,05 \%$
\end{tabular}

Uji coba ini dilakukan untuk menilai keefektifan LKS. Uji coba dilakukan sebanyak empat kali pertemuan, yang dilaksanakan pada 8 siswa kelas VIII SMPK Winya Mandala Tumpang. Uji coba dilaksanakan pada tanggal 19 sampai 21 April. Setiap pertemuan berdurasi 80 menit. Keefektifan LKS hasil uji coba selama tiga pertemuan. Setelah dikonversikan dengan tabel konversi skala, persentase tingkat pencapaian $87,05 \%$ berada pada kualifikasi 81\%-100\% sangat baik. Sehingga LKS ini dikatakan valid (layak) digunakan. Angket penilaian siswa tentang LKS terdiri dari 10 pertanyaan yang diuraikan dengan hasil yakni dinyatakan bahwa 8,75\% siswa lebih senang jika pembelajaran matematika menggunakan LKS berdasarkan masalah kontekstual. 84,37\% siswa berpendapat bahwa penerapan LKS berdasarkan masalah kontekstual berguna bagi siswa dalam mempelajari matematika. 90,62\% siswa berpendapat bahwa LKS berdasarkan masalah kontekstual menarik bagi siswa dan dengan menggunakan LKS berdasarkan masalah kontekstual membantu siswa untuk lebih mudah mengerti matematika. 81,25\% siswa termotivasi untuk mempelajari matematika dengan menggunakan LKS berdasarkan masalah kontekstual. Tanggapan siswa mengenai kesesuaian antara gambar dan materi dalam LKS berdasarkan masalah kontekstual yaitu $75 \%$ sehingga cukup memberikan pemahaman mengenai materi pokok tersebut. Sebanyak $81,25 \%$ siswa berpendapat bahwa uraian materi dalam LKS berdasarkan masalah kontekstual dapat dipahami dengan mudah. Tanggapan siswa mengenai penyajian materi pada setiap kegiatan belajar dalam LKS berdasarkan masalah kontekstual yaitu 93,73\% mengatakan sangat baik. Dan yang terakhir dari komponen penilaian angket siswa, 100\% siswa berpendapat bahwa mereka setuju jika LKS berdasarkan masalah kontekstual diterapkan disekolah. 
Ditinjau dari hasil penilaian setiap komponen, maka diperoleh persentase keseluruhan dari angket siswa adalah sangat baik, karena hasil yang diperoleh yaitu 85,93\% berada pada rentang $81 \%$ sampai $100 \%$. Dengan demikian, media pembelajaran ini dapat dikatakan efektif digunakan tanpa perlu revisi.

Tabel 3. Hasil Penilaian Uji Coba Melalui Nilai KKM dan Nilai Tes Akhir

\begin{tabular}{|c|c|c|c|}
\hline No & Nama & Nilai KKM & Nilai Test \\
\hline 1 & TYA & 70 & 90 \\
\hline 2 & FT & 70 & 75 \\
\hline 3 & AMP & 70 & 90 \\
\hline 4 & LS & 70 & 85 \\
\hline 5 & ANS & 70 & 85 \\
\hline 6 & SVA & 70 & 85 \\
\hline 7 & JKB & 70 & 80 \\
\hline 8 & ZGP & 70 & 85 \\
\hline
\end{tabular}

Berdasarkan hasil nilai tes akhir, dapat disimpulkan bahwa media pembelajaran LKS berdasarkan masalah kontekstual efektif digunakan karena hasil tes siswa telah mencapai KKM yang telah ditentukan oleh sekolahan yaitu 70 . Hasil tersebut dapat dilihat dari perolehan nilai siswa sesudah menggunakan LKS berdasarkan masalah kontekstual.

Selain memberi penilaian pada lembar validasi, validator juga memberikan beberapa komentar dan saran yaitu: (1) Background sampul LKS kurang jelas/buram, perbaiki dengan mengganti gambar dan perjelas; (2) Pengetikan pada kata pengantar perbaiki sesuai dengan petunjuk; (3) Jarak spasi daftar isi diganti menjadi 1,5 spasi.; dan (4) Pada halaman pertama, hanya ada peta konsep, ditambahi dengan KD, indikator, dan tujuan pembelajaran.

\section{SIMPULAN}

Rata-rata hasil validasi oleh ahli materi pembelajaran dan ahli desain pembelajaran sebesar $87,05 \%$, hasil angket siswa sebesar 85,93\%, serta hasil tes evaluasi (uji kompetensi akhir) dari 8 siswa mencapai nilai KKM yang telah ditentukan oleh sekolah. Berdasarkan hasil analisis tersebut, maka LKS berdasarkan masalah kontekstual ini dikatakan valid karena hasil validasi dari kedua ahli berada dalam rentang $81 \%-100 \%$ (sangat baik), dan efektif karena hasil angket siswa juga berada dalam rentang $81 \%-100 \%$ (sangat baik) serta hasil tes evaluasi (uji kompetensi akhir) dari 8 siswa telah mencapai nilai KKM yang telah ditentukan oleh sekolah yaitu 70 .

\section{DAFTAR PUSTAKA}

Astuti, Y., \& Setiawan, B. 2013. Pengembangan lembar kerja siswa (LKS) berbasis pendekatan inkuiri terbimbing dalam pembelajaran kooperatif pada materi kalor. Jurnal Pendidikan IPA Indonesia, 2(1).

Mayangsari, S. N. 2017. Analisis kesalahan siswa dalam pemahaman konsep operasi hitung pada pecahan. Edutic-Scientific Journal of Informatics Education, 4(1). 
Damayanti, N. W., \& Mayangsari, S. N. 2017. Konstruksi Rumus Luas Lingkaran Berbasis Media Manipulatif dengan Setting Pembelajaran Kooperatif, 3(2), 117-124.

Listiyani, I. M., \& Widayati, A. 2012. Pengembangan komik sebagai media pembelajaran akuntansi pada kompetensi dasar persamaan dasar akuntansi untuk siswa SMA kelas XI. Jurnal Pendidikan Akuntansi Indonesia, 10(2).

Masnur, M. 2008. Pengembangan LKS Berdasarkan Masalah Kontekstual Pada Materi Operasi Hitung Bentuk Aljabar. Matematika. Jakarta: Pusat Perbukuan Pendidikan Nasional.

Prastowo, A. 2012. Panduan Kreatif Membuat Bahan Ajar Inovatif. Jogjakarta: Diva Press.

Trianto. 2010. Mendesain Model Pembelajaran Inovatif-Progresif. Jakarta: PT Kencana. 